\section{7. ラット舌に分布する神経要素の発生から発達まで}

一第 1 報一

$\begin{array}{rrr}\text { ○清水 } & \text { 義之・㟝崎 } & \text { 恵・杉本 忠雄 } \\ \text { 福山 } & \text { 宏・上野 } & \text { 正康 }\end{array}$

(九菌大 ・ 口病)

緒言：口腔は消化器系器官の一つであると共に情報伝 達機構の一つでもある. 舌はその中で咀嚼の補助手段と して，また特殊な感覚器官として味覚をも司っており， 噮下，発音の主役として重要な役割を担っている．舌に 分布する神経線維についての㪴究報告は, 主に味覚，と くに味蕾との関係について述べられたものが多い，舌に 分布する神経線維の発生発達については, Vij and Kanagasunthram（1972）が簡単に言及しているに過ぎな い，そこでわれわれは，実験動物にラットを用い，舌に 分布する神経要素の発生から発達までを経日的に観察す る研究に着手した。

研究材料之方法：実験材料には wistar 系ラットを用 いた，今回は，胎生 14 日，17日，生後 1 日，4日，7 日，14日をそれぞれ前頭断 2 例ずつ，矢状断 2 例ずつ観 察を行った．胎生のものは母体の開腹後全身を，生後の ものは撲殺後頭部のみまたは舌のみを取り出し，直ちに 神経固定液に浸漬固定した。，その後通法に従いパラフィ

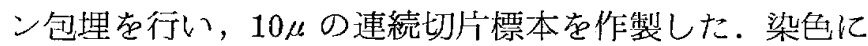
は， H・E 重染色と神経染を施した。

観察結果：胎生14日の舌は拡張した毛細血管を容れる 胎生期間葉組織よりなり, 舌背上皮は 2 層上りなってい る. 舌根部の左:右同側より数十条の大束の神経線維束が 進入している。舌乳頭はみられない，胎生17日において は幼若な筋肉への分化発育がみられる。舌に入る神経線 維も急速に発達し，大東の神経線維群が血管と共に舌根 部より進入し，分散しながら舌㓩方に至っている．各味 覚乳頭の発生もみられるが，味蕾はみられない，生後 1 日においては各朌群の発育が急速に進み，それと共に神 経線維も数, 量とも亿発達し, 乳頭内扔上び舌背上皮下 固有首まで分布している。生後 4 日， 7 日，14日におい ては，それぞれ舌筋の造構，舌の神経要素および乳頭の 発達が観察された。

\section{8. イモリ舌の感覚器の機能について}

$\begin{array}{ccc}\text { ○本田 } & \text { 栄子・山城 } & \text { 哲也・平川 輝行 } \\ \text { 中原 } & \text { 敏 } & \text { (九柬大・生理) }\end{array}$

研究目的：イモリの舌は長さ約 $5.0 \mathrm{~mm}$ ，幅約 $3.0 \mathrm{~mm}$
でカエルに比べ末発達で，舌表面に乳頭様の構造を持た ない，しかし，走査電顕で観察すると，粘膜のとてろぞ ころに表面構造を異にする円形領域が存在し，その細胞 配列は味蕾によく似ている。

イモリ舌の感覚器の性質について生理学的に明らかに した報告はないので，今回，我々はその性質について調 へ，その結果をカエルやアフリカッメガエルと比較し た。

研究方法：実験には体重約 $5 \mathrm{~g}$ のイモリを使用した。 舌咽神経を冠状骨付近で切断し，銀線記録電極にのせ， その応答を直接または時定数 1 の積分回路を介して記録 した。また，受容器電位はガラス管微小電極により記録 した。順応液には飼育に使用している水道水を，また化 学刺激液には, 種々の濃度の $\mathrm{NaCl}, \mathrm{KCl}, \mathrm{LiCl}, \mathrm{NH}_{4}{ }^{-}$ $\mathrm{Cl}, \mathrm{CaCl}_{2}, \mathrm{MgCl}_{2}, \mathrm{HCl}$ ，キニ一ネ溶液を用いた。

研究結果抢よび考察：イモリの舌表面の各部分はいず れも触刺激江上く念答した。種々の塩， $\mathrm{HCl}$ ，キニーネ 刺激では濃度上昇に伴い, 受容器電位の振幅, インパル スを発生する線維数や頻度が増加した。通常のカエルに 比較すると $\mathrm{HCl}$ ，キニーネの闇值は高く，応答線維数 も少なかった，各種塩に対する受容器電位の䦭值は一洒 の壏では $1 / 200 \mathrm{M}$ ，二価の塩では $1 / 800 \mathrm{M}$ でカエルと同様

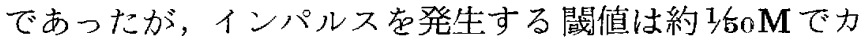
エルよりも高かった。また他の動物と同じように，単一 味細胞が多種類の味物質に応答し, 受容器電位を発生し た. 各塩に対する舌咽神経の応答と受容器電位の振幅 の大きさはそれぞれ，一価の塩では $\mathrm{KCl}>\mathrm{NH}_{4} \mathrm{Cl}>$ $\mathrm{NaCl}>\mathrm{LiCl}, \mathrm{LiCl}>\mathrm{NaCl}>\mathrm{NH}_{4} \mathrm{Cl}>\mathrm{KCl}$, 二価の 塩ではどちらも $\mathrm{CaCl}_{2}>\mathrm{MgCl}_{2}$ であった。一価の塩で の両者の順位の差異が，シナプス伀達機構等に関連する ものかどうか今後調べていきたい。

\section{9. カエル舌咽一舌下神経反射に対する三叉神経上顎枝 の電気刺激の効果について}

$$
\begin{array}{ccc}
\text { ○平川 } & \text { 輝行 - 山田 } & \text { 研治・本田 栄子 } \\
\text { 中原 } & \text { 敏 } & \text { (九雬大 ·生理) }
\end{array}
$$

カエルの上顎外側部门分布する三叉神経上顎汥の電気 刺激が舌咽一舌下神経反射にどのような影響を与えるの かについて検討した。実験にはトノサマガエルを用い， $3 \mathrm{mg} / \mathrm{dl}$ のクラーレ $0.1 \mathrm{ml}$ を筋注した後, 三叉神経上 勁枝，“舌咽神経および舌下神経の分枝である舌骨舌筋 枝，内舌筋枝，才トガイ舌筋枝を露出した．条件刺激は 
三叉神経上顎枝に，試験刺激は舌咽神経に加えた。電 気刺激には通電時間 $0.1 \mathrm{msec} の$ 矩形波を用いた。 反 射放電は舌下神経の 3 つの分枝から直接記録した。 $\mathrm{c}-\mathrm{t}$ interval は $0,5,10 \mathrm{msec}$ とし, 試験刺激, 条件刺 激の強さは $0.3 ， 0.6 ， 1.0 \mathrm{~V}$ とした。それぞれの組合せ における条件刺激の效果を反射放電の放電量, 潜時, 放 電持続時間を比較することにより検討した，舌骨舌筋枝 への反射放電は条件刺激を増强するにつれて放電振幅が 増大し，放電持続時閒が短縮した。内舌筋枝では条件刺 激を增強すると潜時はいくぶん短縮し，放電持続時間も 短縮した．放電量㹥著明に減少した。オトガイ舌筋枝の 条件刺激の効果沈内舌筋枝の場合と同樣であった，以上 の傾向は条件刺激が単一刺激あるいは連続刺激でも同様 であった．また，条件刺激に連続刺激を用いたはうが， その効果は顕著であった。単一電気刺激の場合, 条件刺 激の効果は $\mathrm{c}-\mathrm{t}$ interval が $0 \mathrm{msec}$ に比べて $10 \mathrm{msec}$ のほうが大きかった．連続刺激の場合には，試験刺激が 小さい時, 条件刺激によって内舌筋枝, オトガイ舌筋枝 への反射放電は消失した。

条件刺激によって舌骨舌筋枝への反射放電は潜時の短 い放電に同期して，その振幅か増大し，逆に内舌筋枝，才 トガイ舌筋枝の反射放電は抑制された。乙のととから， 三叉神経の求心性入力は舌の口腔外から口腔内, さらに 口腔底への反射運動を促進するのではないかと考える。

\section{0. 下顎大臼歯の量的解析}

\section{○伊東 励・荒井 秋晴・小林 繁 山田 博 (九崡大 $\cdot 1$ 口解)}

目的：崡は複雑な浮㰹像を呈し，その形態を把握する には三次元的な解析が必要であると思われる. 今回我々 は画像解析装置を用い，歯冠各部の面積および体積を求 め，個々の䨑の特徵を数量的に解析した。

材料：抜去された下㴿右側の第一大臼崡および第二大

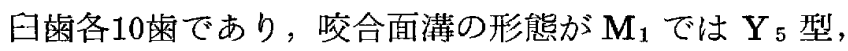

$\mathrm{M}_{2}$ では+ ${ }_{4}$ 型の霆を用いた。

方法：歯冠長軸と水平に歯冠長を 12 等分し，歯頸側上 り順に第 1 区分線加ら第12区分線とし，各部の輪郭を contracer 者用い10倍大に拡大して記録した。乙れらの 輪郭から画像解析装置を用い菌冠各部の断面積预よび体 積を求めた，面積は各輪郭在歯冠近遠心軸および煩舌軸 により, 近心煩側, 近心舌側, 遠心煩側, 遠心舌側の 4 部に分けて行った。体積はてれらの各部において歯冠長
を 4 等分し, 雪頸側 $1 / 4$, 歯冠中央歯顓側 $1 / 4$, 歯冠中央咬 合面側 $1 / 4$, 咬合面側 $1 / 4$ とした。今回は咬合面側 $1 / 4$ を除く 歯冠 $3 / 4$ につて行った。

結果および考察：断面積が最も大きいのは $\mathrm{M}_{1}$ では第 8 区分線, $\mathbf{M}_{2}$ では第 7 区分線であり，歯頸側，咬合面 側一向うに従って順次面積が減じる。すすなち $\mathbf{M}_{1}, \mathbf{M}_{2}$ ともに霜冠中央部で最大であり， $\mathbf{M}_{1}$ の方が $\mathbf{M}_{2}$ よりや や咬合面よりである．霆冠 4 区分の体積では $\mathrm{M}_{1}, \mathrm{M}_{2}$ ともに菊冠中央咬合面側 $1 / 4$ で最も大きく，歯顓側と咬合 面側との差は $\mathbf{M}_{1}$ の方が $\mathbf{M}_{2}$ より大きい。乙れは $\mathbf{M}_{1}$ が $\mathbf{M}_{2}$ 亿比へ歯冠の発達がよく, 雪頸部の狭窄が強いとい う形態の表現であると思われる．近心半と遠心半の占め る割合の差は断面積, 体積ともに $\mathrm{M}_{1}$ の方が $\mathrm{M}_{2}$ より大

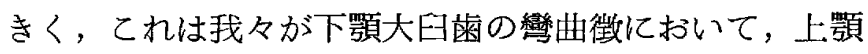
の曰䨑を除き同一菌群において退化傾向の強い粜ほど彎 曲徵は弱くなる，とした先の報告と一致するものであ る. てれらの結果から画の形態を数量的に解析するてと により，形態をより的確に把握するととが出来るものと 思われる。

\section{1. 下顎前歯の植立について}

\section{○佐藤 清高・豊田 静夫}

(九雨大・1 補綴)

上顎前菌部は審美性と非常に密接な関係があるため， 画牙の形態打よび植立状態について, 從来多くの研究報 告がある.ところが下龥前兩は, 談話時, 微笑時に見え るにもかかわらず，その形態および植立状態に関しては ほ上んご検討されていない。

そこで，被検者の上下顎印象を採得して模型を作製 し, 補綴学的平面を基準平面として咬合器に模型を付着 した後，下颚模型上で前蒾の正面形態と植立状態につい て計測を行い，娭討を加えた。被検者は，20歳代(30 名)，30歳代（13名），40歳代（13名）の個性正常有歯顎 者とした。

結果は以下のと抢りである.

1. 臨床的歯冠長 ( $\mathrm{I}-\mathrm{G}$ 点間の垂直距離) は, 各年 代間ではほとんど差はなかった。

2. 歯冠側鼓形空陌の頂点 (IEA) は，年代間ではほ とんど差は認められなかったが，雬肉側鼓形空隙の頂点 (GEA)は，加齢ととも澺有に下降していた。

3. 歯冠乳頭の高さ（I-P点閵の垂直距雁）は, 加 齢とともに有意に下降していた。 